\title{
A convergência analítica dos herdeiros de Kautsky e Nozick: crítica às interpretações da direita e da esquerda estatista sobre o Levante de 2013 no Brasil
}

\section{The convergence of analytical and Kautsky Nozick's heirs: criticism of interpretations of right and statist left on the 2013 uprising in Brazil}

Wallace dos Santos de Moraes Doutor em Ciência Política pelo Instituto Universitário de Pesquisas do Rio de Janeiro (IUPERJ) Professor Adjunto da Universidade Federal do Rio de Janeiro wktmoraes@outlook.com

\begin{abstract}
Resumo: Trata-se de apresentação de discussão bibliográfica acerca do Levante popular brasileiro ocorrido em junho de 2013. Objetivamos apontar as diferentes perspectivas da Revolta realizadas por teóricos de matrizes distintas. A pesquisa ampara-se em nossa observação participante do processo, particularmente na cidade do Rio de Janeiro. Percebemos o perfeito casamento da filiação ideológica do analista perscrutado com uma visão particular sobre a revolta popular. Nosso artigo traz uma interpretação libertária do levante de junho muito marginalizada nos meios acadêmicos, não obstante, muito comum nos meios mais combativos. A pesquisa busca sobretudo garantir a memória do maior Levante popular da história brasileira.
\end{abstract}

Palavras-chave: Teoria Política. Memória histórica. Revolta popular. Junho de 2013. Perspectiva anarquista.

\begin{abstract}
It is a presentation of bibliographical discussion towards the brazilian popular Uprising occurred on June 2013. We sought to point out the different perspectives from contrasting theorists on the Rebellion. The research is based on our participant observation of the process in Rio de Janeiro. We have noted the perfect match of the studied analyst's ideological affiliation with a particular perspective on the popular uprising. Political interests were crucial for the conclusions from different intellectuals. Our article brings na anarchist interpretation on the June's uprising that is pretty much marginalized in the academia, nevertheless, really common in more combative segments. Most of all, the research seeks to ensure the memory og the biggest popular uprising in brazilian history.
\end{abstract}

Keywords: Political theory. Historical memory. Popular uprising. June 2013. Anarchist perspective.

Originais recebidos em: 08/08/2015

Aceito para publicação em: 08/09/2015

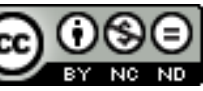

Este trabalho está licenciado sob uma Licença Creative Commons Atribuição-Uso NãoComercial-Vedada a criação de obras derivadas 3.0 Unported License. 
O período entre junho de 2013 e julho de 2014 foi um dos mais importantes da história da mobilização política e social do Brasil, em particular, do Rio de Janeiro. Os maiores protestos da história do país, greves de garis, rodoviários e professores a despeito da orientação das direções sindicais em contrário. "Rolezinhos" de moradores de favelas e periferias para explicitar o, por vezes, dissimulado apartheid brasileiro. Em função do péssimo serviço dos transportes e da forte repressão policial discriminatória, populares fizeram barricadas em seus bairros, favelas e quebraram trens, ônibus, barcas e metros. Até os jogadores da elite do futebol brasileiro cruzaram os braços e protestaram antes, durante e depois das partidas. Vimos os oligopólios de comunicação, a polícia, o Estado, todos os governantes, partidos políticos, sindicatos, transportes públicos e os bancos serem amplamente contestados/rechaçados. Um ano sui generis. Deve entrar para a história, mas sobretudo deve ter preservada a sua memória com uma análise problematizadora. Esse é o nosso objetivo.

As jornadas insurgentes do inverno-primavera de 2013, cujo paroxismo aconteceu nas manifestações da semana de 17 a 23 de junho, já podem ser computadas como as maiores da história do Brasil. Nada se iguala em número de pessoas nas ruas, ainda que se considerem os levantes populares e suas diversas revoltas isoladas. Pari passu, em nenhum momento houve tantos enfrentamentos simultâneos com a polícia, praticamente em todas as capitais no país e em grandes cidades na mesma semana, consubstanciando-se em evidência do teor da revolta popular. ${ }^{1}$

Normalmente, as sociedades que passam por processos insurrecionais deixam um gérmen de um novo mundo e é claro que em disputa com o velho e moribundo. Trata-se de um movimento único, muito rico e que precisa ser teorizado, pormenorizado e registrado nos anais da História.

Como o Brasil é um país continental e as manifestações aconteceram simultaneamente em todos os estados da federação, foi impossível a qualquer observador participante acompanhá-las em tempo real. Portanto, o que segue são reflexões sobre a Revolta dos governados na cidade do Rio de Janeiro, embora os motivos, o modus operandi, e as

\footnotetext{
${ }^{1}$ A Artigo 19 (2013) fez um levantamento sobre os protestos no ano de 2013, chegando às seguintes conclusões: entre $1^{\circ}$ de janeiro e 31 de dezembro de 2013 ocorreram: 691 protestos; 15 manifestações com mais de 50 mil pessoas; 16 manifestações com mais de 10 feridos; 10 usos de armas de fogo; 8 mortes; 837 feridos; 2608 pessoas detidas; 117 jornalistas agredidos ou feridos; 10 jornalistas detidos.
} 
características tenham sido muito similares em todo o país pelo que podemos constatar a partir do midiativismo.

Comentando sobre os protestos na Turquia, Slavoj Zizek disse o seguinte:

A luta pela interpretação dos protestos não é apenas 'epistemológica'; a luta dos jornalistas e teóricos sobre o verdadeiro teor dos protestos é também uma luta 'ontológica', que diz respeito à coisa em si, que ocorre no centro dos próprios protestos. Há uma batalha acontecendo dentro dos protestos sobre o que eles próprios representam.

Igualmente, no Brasil, há uma grande disputa sobre a narrativa do levante popular de 2013. Por razões ideológicas e político-eleitorais, diversos intelectuais participam de uma querela sobre os motivos da revolta de junho de 2013, bem como suas características. Objetivamos apresentar as diferentes interpretações sobre as jornadas insurgentes e apontar elementos para identificar o que está por trás de cada uma. Faremos um debate sobre as formas de construção da história dos fatos. Depois, discutiremos as análises propriamente em disputa. No bojo dessa discussão, apresentaremos nossas teses a partir da observação participante. Pretendemos dar voz aos setores populares mais atuantes do Levante popular de 2013 no Brasil, por meio da tradução de sua ação direta que deixou perplexos e atônitos, num primeiro momento, os governantes de um modo geral, tanto da direita, quanto da esquerda, institucionais.

Antes de apresentarmos os fatos propriamente, cumpre explicarmos nossa opção teórica e as respectivas ressalvas metodológicas.

\section{Métodos e conceitos para análise do levante de 2013}

Boaventura de Souza Santos (2011: 29) assevera que vivemos nas ciências sociais, hoje, a monocultura do saber e do rigor que preconiza como único dado rigoroso o científico; por consequência, todo o conhecimento alternativo, popular, é destruído. Ele denomina este fenômeno de "epistemicídio".

Utilizaremos o conceito vislumbrado por Santos com propósitos um pouco mais amplos, na busca por apreender outros aspectos da ciência social, pois o epistemicídio não nega apenas o conhecimento produzido fora da Universidade, sem o rigor científico, como refletiu Santos - fato que já é gravíssimo -, mas para além disso, corroborando para o aumento do grau de gravidade, ele assassina no nascedouro todas as opções teóricas-metodológicas produzidas na academia que negam o Estado e o capitalismo enquanto instituições legítimas e necessárias para o bem-viver da humanidade. Em outras palavras, sobrevivem ao 
epistemicídio, hoje, somente as teorias, produzidas na academia e/ou nos grandes oligopólios de comunicação de massa, que concebem o capitalismo e suas instituições, principalmente o Estado, como legítimos e no máximo passíveis de reformas. Não se constitui, portanto, em mero preconceito em relação àquilo que é produzido fora da academia, mas a todo conhecimento crítico ao establishment.

Certamente, se a produção intelectual for de fora do mundo acadêmico e ao mesmo tempo contestar o sistema como um todo será mais facilmente rejeitada por esses doutos em defender o Estado, a desigualdade e a limitação da liberdade para alguns. Todas as teorias que se enquadram no princípio geral de conceber as instituições estatais como resultado do progresso e da razão são aceitas. São elas: o liberalismo, a social-democracia, o marxismo reformista e o conservadorismo. Todas concordam em torno da existência do Estado e consequentemente da dicotomia entre governantes e governados. Pode-se pensar em diferentes formas de exercício do poder estatal, mas jamais na sua negação. São os fantasmas hobbesiano-hegelianos impondo suas assombrações. ${ }^{2}$

Destarte a ciência social oficial realiza o epistemicídio, cujas principais características são a idolatria do Estado, que chamaremos daqui em diante por estadolatria ${ }^{3}$, bem como, o impedimento de se pensar em outras organizações societais para além dos limites do capitalismo como se existisse uma camisa de força que obstasse reflexões mais generosas para a díade: autonomia-emancipação.

Por conseguinte, o epistemicídio ataca todas as experiências populares e teóricas que não se enquadram nos padrões de exaltação do Estado, do capitalismo e não se encontra dentro dos moldes "científicos" acadêmicos, positivistas, amplamente parciais sob a égide da neutralidade axiológica.

No mesmo diapasão, Castoriadis (2007: 69) ressalta que grande parte dos pensadores tentou ocultar o fato de que a sociedade se auto-institui, buscando apresentar suas instituições como tendo uma origem extrassocial, divina, racional ou como sendo fundada em leis da história. O principal objetivo dessa ocultação é retirar por completo o papel dos homens na criação do seu próprio mundo. É a obliteração da crítica das instituições existentes bem como

\footnotetext{
${ }^{2}$ Tanto Thomas Hobbes, quanto Hegel são expoentes do pensamento político que concebe o Estado como uma instituição absolutamente necessária para a melhor organização da sociedade.

${ }^{3}$ Essa tradição ganha força durante o renascimento italiano, sendo reforçada a posteriori pelos teóricos modernos. Suas principais características foram: 1) legitimar retrospectivamente o Estado e toda sua estrutura de poder e coerção; 2) considerar a vida do Estado como central para a história; 3) estabelecer o raciocínio histórico como se não fosse possível vivermos sem ser governados por outros.
} 
da possibilidade de criar/resgatar novas formas de convívio social. Partimos do princípio, por consequência, de que a sociedade deve ter a liberdade de se autoinstituir. Com efeito, a história deve ser tratada como autoinstituição dos homens.

Outro tema central da análise libertária é o estudo do papel exercido pelos revolucionários, pelos movimentos sociais autônomos, pelas revoltas contra os opressores por igualdade, liberdade e sobrevivência. Com efeito, faremos o resgate da memória dos movimentos e/ou dos lutadores do povo que deve servir pedagogicamente como contraponto à história dos reis, das cortes, dos governantes e dos ricos e poderosos realizada pela historiografia oficial.

Em síntese, o método anarquista baseia-se na ideia de que a ação direta dos governados constitui-se enquanto motor da história, isto é, é o movimento popular autônomo tomando as ruas, fazendo greves, organizando-se coletivamente, que pode fazer as mudanças substantivas para melhoria da qualidade de vida, como um verdadeiro processo de autoinstituição. Nesse sentido, o nosso diferencial é estabelecer uma teoria das ruas e não uma teoria para as ruas. Uma teoria das ruas deve estar comprometida com os sinais emitidos por elas, problematizando-os, tentando decifrá-los. Diferente de outras perspectivas que querem tutelar os governados, dizendo a eles o que deveriam ter feito ou devem fazer, nós queremos entender os seus sinais. A primeira perspectiva parte de um plano pré-estabelecido; a nossa, deve aprender junto e construir coletivamente o novo mundo. Deixemos os governados se autoinstituirem.

\section{Ressalva metodológica}

Do ponto de vista metodológico, existem três maneiras de se produzir teorias sobre a revolta dos governados de 2013 no Brasil. Uma dessas é pela lente da televisão. Em outras palavras, caso o analista tenha ficado em casa assistindo parte dos acontecimentos que foram transmitidos, alguns deles ao vivo, produzirá uma análise enviesada pela censura das câmeras e pelos comentários dos jornalistas muito bem pagos para criminalizar toda e qualquer revolta popular contra o establishment. É necessário lembrar que todos os repórteres identificados nas passeatas foram imediatamente expulsos pelos manifestantes, pois estes sabiam como as notícias eram tendenciosamente produzidas contra o movimento. As imagens, com efeito, foram produzidas por jornalistas disfarçados, do alto dos prédios e/ou por helicópteros das emissoras. Quase a totalidade das resenhas publicadas nos diversos jornais e revistas ou 
mesmo divulgadas por entrevistas e comentários nas televisões, rádios e internet sobre o processo foram produzidas a partir das lentes televisivas e com a sua já sabida censura. ${ }^{4} \mathrm{As}$ análises sob estas condições, salvo raríssimas exceções, incorreram em erros absurdos e colaboraram diretamente para a reprodução dos preconceitos difundidos pelos oligopólios midiáticos.

Feita essa ressalva metodológica, passemos às principais argumentações desenvolvidas por diferentes intelectuais sobre o Levante popular de 2013.

\section{Análises em conflito sobre a revolta popular de 2013}

Ao examinarmos a insurreição popular de 2013 no Brasil, identificamos a existência de pelo menos cinco interpretações puras e algumas outras que se constituem como amálgama de duas delas ou mais. Das cinco, duas são oficiais pois caminham dentro dos limites da institucionalidade vigente, são elas: ultraliberal e a governista (petista) ${ }^{5}$. As principais características de suas análises foram clamar pela integridade: do Estado, das instituições, da democracia representativa, enfim, do status quo. Essas partiram dos postulados da democracia minimalista e apresentaram o capitalismo e o Estado, com suas instituições, como último estágio e mais avançado da história da humanidade como impassíveis de alterações. Elas foram amplamente divulgadas pelos oligopólios de comunicação de massa no Brasil. As outras três análises vieram: da esquerda estatista, dos integralistas (fascista) e dos setores revolucionários.

Podemos resumir as cinco interpretações para o caso específico da Revolta dos governados, da seguinte maneira:

Governista: divulgada pelos jornalistas e intelectuais simpatizantes do petismo, cujo principal objetivo foi isentar o governo federal de responsabilidade pelo descontentamento popular. Buscou levar a crer que o povo estava nas ruas não contra os pseudos representantes políticos e suas instituições, mas por questões absolutamente laterais que essa mesma intelectualidade focou como essencial. Ainda apresentou a tese de que o movimento popular era manipulado por setores de direita que queriam diminuição de impostos e/ou tomar o poder

\footnotetext{
${ }^{4}$ Os oligopólios de comunicação de massa no Brasil historicamente assumiram uma postura antipoder popular, criticando suas reivindicações, greves, passeatas, etc.

${ }^{5} \mathrm{Da}$ nossa parte, não lemos o governo do partido dos trabalhadores como parte da esquerda estatista, pois através de suas políticas públicas implementa um programa muito similar ao partido neoliberal que o antecedeu no poder, o PSDB, de Fernando Henrique Cardoso. Ambos partidos, embora se apresentem como oposições um ao outro, implementam uma política muito semelhante em todos os sentidos.
} 
por meio de golpe militar e tentou induzir fortemente que se tratava de manifestantes de classe média.

Ultraliberal: propalada por aqueles que aproveitaram a revolta para criticar o governo federal a partir de conjecturas características da teoria de Nozick, Hayek e outros. Buscou encontrar no Levante popular atributos que atendessem aos seus anseios políticos-eleitorais apresentando críticas liberais ao governo federal. As ações diretas foram narradas como desprovidas de qualquer cunho político, somente como ato de "vandalismo". A figura do vândalo-terrorista infiltrado cumpre o papel da figura espetacular à esquerda, cuja suposição deveria introduzir um suposto inimigo comum, unindo a população contra o governo.

Reformista: realizada pelos intelectuais ligados aos partidos da esquerda estatista. Esta percebeu o processo de duas formas antagônicas: a) positiva, pois colocou em xeque o governo (situação), aumentando suas possibilidades de um êxito eleitoral; b) negativa, pois o processo não foi dirigido por ela e não atendeu aos seus anseios eleitorais. A penetração social da esquerda estatista é bastante pequena, a verificar pelos seus votos nas últimas eleições nacionais em 2014, quando não alcançou nem $2 \%$.

Fascista: realizada por grupos minúsculos, com mínima penetração social, advogaram por um golpe militar para "instaurar o integralismo" reformista criticou os ataques às instituições estatais e do capital.

Revolucionária: propalada por diversos coletivos combativos e não institucionais muitos deles adotaram a tática Black Bloc. Foi a grande novidade entre os atores políticos. Negou todos os governos e defendeu o levante como ele foi, com algumas críticas pontuais, mas exaltando a ação direta, a horizontalidade, a combatividade dos manifestantes e o empoderamento popular sem intermediários.

Quadro descritivo das interpretações sobre o Levante e das forças políticas que as compõem.

\begin{tabular}{|c|l|}
\hline Interpretações & \multicolumn{1}{|c|}{ Forças políticas que a compõem } \\
\hline Governista & $\begin{array}{l}\text { Jornalistas dos oligopólios de comunicação de massa no Brasil; } \\
\text { governantes, intelectuais e políticos dos partidos da situação: PT, } \\
\text { PMDB, PCdoB, PDT. Sindicalistas ligados às centrais sindicais } \\
\text { dirigidas por esses partidos. Empreiteiros, banqueiros, empresários e } \\
\text { capitalistas em geral alinhados e apoiadores das ideias liberais }\end{array}$ \\
\hline
\end{tabular}

\footnotetext{
${ }^{6}$ Integralismo foi um movimento liderado por Plínio Salgado, nos anos 1930 no Brasil, e advogava muitos dos princípios do fascismo europeu.
} 


\begin{tabular}{|c|l|}
\hline $\begin{array}{c}\text { Ultraliberal } \\
\text { (oposição de direita } \\
\text { ao governo) }\end{array}$ & $\begin{array}{l}\text { Jornalistas dos oligopólios de comunicação de massa no Brasil; } \\
\text { governantes, intelectuais políticos dos partidos da oposição "oficial": } \\
\text { PSDB, DEM, PTB, PPS, PSB. Empreiteiros, banqueiros, empresários } \\
\text { e capitalistas em geral alinhados às ideias ultraliberais. }\end{array}$ \\
\hline $\begin{array}{c}\text { Esquerda estatista } \\
\text { (oposição de } \\
\text { esquerda ao } \\
\text { governo) }\end{array}$ & $\begin{array}{l}\text { Intelectuais e políticos do PSOL, PSTU, PCB, movimentos sociais e } \\
\text { principalmente sindicatos ligados a esses partidos. }\end{array}$ \\
\hline $\begin{array}{c}\text { Fascista } \\
\text { Revolucionária }\end{array}$ & $\begin{array}{l}\text { Integralistas - grupos minúsculos que reivindicam uma espécie de } \\
\text { fascismo com matizes brasileiras e tropicais. } \\
\text { marxistas não eleitorais/movimentos sociais ligados a luta pela } \\
\text { moradia e outros. }\end{array}$ \\
\hline
\end{tabular}

Fonte: elaboração própria.

No escopo deste paper não é possível passar em revista todas as interpretações sobre a revolta no Brasil. Focaremos somente na convergência das análises das interpretações governistas, ultraliberais e da esquerda estatista.

Passemos em revista agora os aspectos metodológicos, teóricos e as interpretações do levante por essas diferentes perspectivas. Comecemos pelas análises oficiais.

\section{Características das análises oficiais}

Ao longo da história da humanidade, a ampla maioria dos historiadores/cientistas sociais produziu uma historiografia/ciência social, que chamamos de oficial ${ }^{7}$, com um objetivo muito claro: legitimar e justificar o poder estabelecido. ${ }^{8}$ Sob essa perspectiva, muitos pseudo-teóricos, ou mesmo alguns renomados, sob o manto da isenção (atualmente, conhecida como neutralidade axiológica), "teorizaram" sobre a realidade do ponto de vista

\footnotetext{
${ }^{7}$ A historiografia oficial construiu a história jogando luz sobre o papel das Cortes, do Estado, da burguesia e das leis. As revoltas, os levantes, as revoluções, normalmente não aparecem, mas quando é inevitável, são apresentadas como acidentes da história que obstaculizam "o bom percurso do progresso da humanidade".

8 Certo é que legitimar o poder político e econômico nunca foi exclusivo dos historiadores, mas indubitavelmente certificado por eles. Na Idade Média, por exemplo, os padres cumpriam um papel mais importante; e na contemporaneidade, a grande mídia. Para bela reflexão sobre este assunto, ver Fontana (2004).
} 
mais ideológico imaginável, abordando-a da maneira mais irreal possível e apontando soluções pitorescas para seus problemas.

As disputas entre as correntes ultraliberais e governistas reduzem-se ao modelo de gestão adotada por cada uma: ambas disputam o amparo dos grandes banqueiros, industriais, empreiteiros e representantes de peso dos capitalistas, donos do "mercado". Os oligopólios de comunicação de massa apresentam as teses dessas oposições quase que exclusivamente para a sociedade como se fossem as únicas. No entanto, no que concerne à interpretação sobre o Levante, elas convergem em larga escala porque foram igualmente contestadas/rechaçadas pelas ruas. Trataremos inicialmente dos seus postulados comuns e depois abordaremos as características idiossincráticas de cada uma. Quando falarmos sobre o que possuem em comum, a denominaremos por interpretação oficial. Comecemos.

Do ponto de vista teórico, a interpretação oficial é guiada pela perspectiva liberal e, particularmente, pela teoria da democracia minimalista, segundo a qual as manifestações de rua atrapalham o bom andamento da democracia, pois colocam demandas para o governo que ele não pode atender em função dos seus compromissos com as contas e as leis do mercado (accountability). Isto é, os interesses do mercado, dos capitalistas, estão acima das reivindicações da população. Na teoria política são muito comuns essas análises. Autores como Schumpeter (1984), Lipset (1963) e diversos outros são expoentes daquilo que poderíamos chamar de teóricos da democracia minimalista.

Da perspectiva metodológica, é mister ressaltar que a filiação ideológica do autor foi fundamental para suas escolhas. Em sendo liberal, conservador, simpatizante do governo, ou crítico deste a partir das teses ultraliberais tendeu a buscar meios de criticar o mais fortemente as manifestações, sobretudo por aspectos moralistas. Mesmo que por vezes cinicamente alegasse que eram legítimas. Apresentou suposições para dizer que os protestos não foram populares, mas de classe média que não teria o que reivindicar, pois possui condições de obter seus direitos através do mercado.

Outro aspecto desse campo intelectual foi a defesa autoritária das instituições estatais e de mercado existentes, como se elas expressassem o último estágio da evolução humana e, portanto, portadora da razão, no termo de Hegel. Essa opção analítica está embebida tanto pela ideia do fim da História, completamente guiada por uma miragem evolucionista, como, ademais, busca negar, por completo, o conceito de autoinstituição. Ou seja, não é permitido à sociedade negar as instituições existentes, pois estas significam o que há de mais avançado, 
racional, evoluído e democrático, asseveraram. Um absurdo incomensurável e conservador que obsta o papel da humanidade de construir e recusar o establishment. Nega o papel aos homens de construírem sua própria história.

Essas análises partem de um postulado pré-estabelecido: defender o governo ou a sua oposição oficial, bem como, as instituições do Estado e do capital. Assim, buscam as fontes com interrogações que possibilitem apenas legitimar seus objetivos iniciais em favor dos governantes. Os historiadores até o início do século XX eram guiados por essas perspectivas, chamados por Fontana (2004) de legitimadores dos donos do poder.

Os oligopólios de comunicação de massa, os governistas e seus jornalistas e intelectuais orgânicos, nunca quiseram o povo nas ruas, por questões óbvias. Porém, como não podiam passar por autoritários, usaram um discurso ambíguo defendendo que a população podia se manifestar, contudo sem direcionar toda sua raiva acumulada por anos de subordinação e exploração contra quem lhes ataca. Eles usaram os termos: depredação e "vandalismo" para depreciar os governados que revidaram os ataques policiais e por consequência quebraram vidraças de bancos e de prédios estatais. Um discurso moralista e criminalizante contra a revolta popular, centrado na perspectiva do "homem cordial" de Sérgio Buarque de Holanda (2001) e seus seguidores, ou mesmo do Brasil ordeiro, cujas elites dominantes são generosas com seus subordinados no veio de Gilberto Freyre (1998) e outros. O fio condutor dessas análises partiu do ponto de vista da manutenção do status quo, sem mudanças substantivas.

No início do movimento, esses setores simplesmente ignoraram que existia a manifestação. Depois que ela cresceu em função da nova comunicação pelas redes sociais, passaram a divulgá-la, entretanto buscando controlar sua orientação. Esta visão tentou, também, deturpar suas demandas sociais e colocar como prioritário algo que não esteve presente, ou exacerbar aquilo que figurou apenas lateralmente, como dizer que a população necessitava de uma reforma política e lutava contra a corrupção. Algo absolutamente dentro do sistema e que efetivamente não apontava para mudanças concretas para o bem-estar dos trabalhadores. Assim, tratava-se de uma reivindicação fluida que fugia do principal. Essa corrente interpretativa "esqueceu" que a luta começou pelo passe livre - tarifa zero - por um transporte sem roletas e depois se ampliou com uma pauta abrangente que incluía dentre outras coisas uma crítica contundente a todos os partidos e políticos em geral, e contra muitos dos pilares do mercado capitalista existente no Brasil, como mostraremos mais à frente. Além 
disso, os conservadores criticaram a ausência de líderes que conseguissem representar a todos, ignorando que essa ausência era a maior expressão do movimento apresentando-se como horizontal e múltiplo, constituindo-se em sua maior riqueza.

No afã de atacar a Revolta dos governados, desmerecendo-a, várias leituras desse campo chegaram ao desatino de asseverar que "elas não tinham nada demais" (Oliveira, 2013) ou possuíam um caráter fascista (Santos, 2013). Um erro grosseiro que demonstra simultaneamente o descuido ou o total desconhecimento do analista tanto das ideias e ações fascistas ${ }^{9}$; quanto da história popular brasileira e dos seus signos produzidos nos últimos anos. Esta perspectiva é guiada indubitavelmente por um veio eurocentrista, buscando encontrar no Brasil as mesmas glosas europeias.

Esse tipo de julgamento abriu margem para a construção de um pseudo consenso com vistas a criminalizar os setores mais radicalizados anticapitalistas, dos estudantes e populares que participaram das manifestações na linha de frente. Em resumo, tratou-se da tentativa dos ocupantes dos altos postos políticos do país e de alguns intelectuais orgânicos de dividir os manifestantes em dois grupos: os "bonzinhos" que exerceram seu papel de cidadania ordeiramente, foram para as passeatas de verde e amarelo, pintaram o rosto, portaram bandeiras brasileiras e cantaram entusiasticamente o hino nacional. Em suma, mais uma vez a ideologia do nacionalismo foi usada para subordinar o povo. Do outro lado, segundo essa visão, estavam os maus, os bandidos, os vândalos, os anarquistas, os Black blocs que queriam depredar o patrimônio público e estabelecer a desordem no país, desrespeitando suas instituições (Santos, 2013). Sorrateiramente tiraram todo o conteúdo reivindicativo e qualquer possibilidade de auto-instituição (Chauí, 2013; Oliveira, 2013; Musse, 2013, Singer, 2014), buscando deslegitimar a ação direta popular nas ruas contra anos de opressão estatal e capitalista.

Essa tese, formando quase um consenso, foi amplamente divulgada pelos grandes oligopólios de comunicação de massa no Brasil; por diversos políticos tanto dos poderes Executivos, quanto dos Legislativos e seus respectivos partidos (PT, PMDB, PCdoB, PSDB, DEM, PTB, PDT, PPS e outros menores); por grande parte dos empresários, empreiteiros e

\footnotetext{
${ }^{9}$ As perspectivas fascistas caracterizam-se pelos seguintes aspectos: hierarquização social com claro comando centralizado representado por um líder (führer) através de partido político único, forte disciplina, nacionalismo extremado. Aspectos que sem dúvida a horizontalidade e a clara negação de qualquer comando centralizado do processo durante os protestos no Brasil refutam por si só.
} 
banqueiros que se locupletam das políticas públicas e de contratos vantajosos com o Estado. Simultaneamente, de forma cínica pronunciaram que todos tinham o direito de se manifestar.

Outra polêmica girou em torno da classe social dos manifestantes. Para as interpretações governistas, interessava explicar que não se tratava do povo indo às ruas, mas de uma classe média que possui tudo do bom e do melhor. Ela foi às ruas sem motivos, apenas por hobby (Chaui, 2013), ou por interesses políticos de um campo obscuro como se fossem de direita e fascistas para desestabilizar o governo (Singer, 2014). Assim, essas interpretações tentaram emplacar a ideia de que as manifestações eram de classe média seja por uma perspectiva positiva (Maricato, 2014), seja negativa (Chaui, 2013; Singer, 2014), ou mesmo mostrando-se perplexo com o fato de a classe média reivindicar direitos que lhes são amplamente disponíveis pelo mercado (Cardoso, 2013). ${ }^{10}$ Entendemos que se trata de uma discussão absolutamente estéril que tem como resultado principalmente retirar o foco do essencial. Só interessa entrar nesse debate quem não quer discutir exatamente os sinais emitidos pelos manifestantes. Até porque, de acordo com os dados oficiais, o conceito de classe média não tem mais vinculação com a percepção popular, segundo a qual, seria formada por pessoas com confortável modo de vida com casa própria, carro novo etc. Esse conceito foi ressignificado pelo próprio governo de modo a incluir o maior número de pessoas pobres como parte da classe média, criando uma farsa a partir da estatística. Com efeito, somente pode-se considerar pobre aquele que recebe uma renda per capita inferior a $\mathrm{R} \$ 140$ por mês, equivalente a $\mathrm{R} \$ 4$ por dia. Sinceramente, com esse valor não é possível fazer nem duas refeições diárias. A classe média receberia entre $\mathrm{R} \$ 291,00$ e $\mathrm{R} \$ 1019$ per capita. Nesse contexto, uma empregada doméstica que recebe um salário mínimo no Rio de Janeiro, $\mathrm{R} \$ 874,75$, e tem dois filhos para sustentar é considerada como classe média pelo governo.

\section{Análises ultraliberais através dos oligopólios de comunicação de massa}

Podemos dividir a postura do pensamento ultraliberal sobre o Levante popular em três diferentes momentos: $1^{\circ}$ ) tentou ignorar que havia protestos; $2^{\circ}$ ) disputou a direção do movimento; $3^{\circ}$ ) defendeu a criminalização dos que eles chamaram de "vândalos". Chegamos a essas conclusões a partir da análise dos discursos de Arnaldo Jabor, representante do quadro jornalístico da Rede Globo e um dos símbolos do pensamento ultraliberal no Brasil. Vejamos.

\footnotetext{
${ }^{10}$ Todas essas análises amparam-se em números divulgados pelos oligopólios de comunicação de massa com a sua já sabida tentativa de desmerecer os protestos.
} 
Arnaldo Jabor, jornalista da Rede Globo ${ }^{11}$, transformou-se, num primeiro momento, em ícone às avessas da Revolta dos governados. Na sua fala de 12 de junho de 2013, Jabor (2013a) arrazoou vários argumentos que ficaram marcados e que foram retomados por diferentes intelectuais ao longo do processo. Percebamos como todos estes tinham por objetivo deslegitimar os protestos: 1) defendeu que o movimento não tinha motivos legítimos para ir às ruas, que $\mathrm{R} \$ 0,20$ era muito pouco; ${ }^{12}$ 2) disse que a composição era de meninos de classe média e que não havia pobres que necessitassem $\operatorname{dos} \mathrm{R} \$ 0,20$; 3) associou o quebraquebra das manifestações a ataques de organização criminosa; 4) colocou os policiais que ganham muito mal, segundo ele, como vítimas dos meninos de classe média, ameaçados com coquetéis molotov; 5) atrelou os descontentamentos a uma imensa ignorância política; 6) afirmou que os manifestantes não tinham causas, nem pauta; 7) no final da sua fala, sugeriu que lutassem pelo fim da PEC $37^{13}$; 8) esbravejou: "os que lutam defendem o socialismo da década de 1950"; 9) aproveitou e fez críticas ao governo federal em função da inflação alta etc; 10) terminou dizendo: "realmente esses revoltosos de classe média não valem nem $\mathrm{R} \$ 0,20 . "$

Esse discurso gerou uma grande indignação na sociedade que foi para a rua dizer que “não era por apenas R $\$ 0,20$, mas por direitos.” Vários cartazes continham essa frase. Essa intervenção de Jabor, conhecido ícone do pensamento ultraliberal no Brasil, pautou muitos dos pronunciamentos subsequentes de intelectuais governistas, da esquerda estatista e da direita neoliberal. Com o enorme crescimento do movimento, Jabor teve que fazer a meaculpa, mas continuou a propor um pleito da democracia minimalista, idólatra do Estado mínimo, e, evidentemente, dentro da institucionalidade (Jabor, 2013b).

Inaugurava-se o segundo momento da postura do pensamento ultraliberal sobre os protestos. Em suma, a grande mídia sentiu a perda de espaço e se apresentou como se estivesse ao lado dos manifestantes.

A tergiversação de Jabor representou a de toda a grande mídia. Ela aconteceu por vários motivos: 1) o número de pessoas nas ruas aumentava exorbitantemente; 2) os protestos eram os principais assuntos das redes sociais; 3) em função da postura dos grandes

\footnotetext{
${ }^{11}$ Maior conglomerado de mídia na América Latina. Seu império foi construído durante a ditadura militar, com amplo apoio recíproco. Sempre se colocou contra as manifestações populares no país. Em 2013 não foi diferente. ${ }^{12} \mathrm{R} \$ 0,20$ foi o valor do aumento do transporte público que serviu de estopim para o início dos protestos.

${ }^{13}$ A PEC 37 sugeria incluir um novo parágrafo ao Artigo 144 da Constituição Federal com a seguinte redação:

"A apuração das infrações penais de que tratam os $\S \S 1^{\circ}$ e $4^{\circ}$ deste artigo, incumbem privativamente às polícias
} 
oligopólios de comunicação de massa, os manifestantes os viam como verdadeiros inimigos. A título de exemplo, carros das emissoras foram queimados e jornalistas foram prontamente expulsos dos protestos; 4) a credibilidade da grande mídia nunca esteve tão abalada nacionalmente. Por tudo isso ela teve que tergiversar sua posição.

As análises de Jabor (2013c) representaram bem esse transformismo. Ele começou como toda a mídia a endossar as reclamações, mas impondo as suas postulações como a do movimento, significando a apologia da institucionalização da luta. Nesse sentido, acastelou que houvesse líderes e ideias institucionais, escolheu alvos de ação, como a luta contra a PEC 37 e propôs ainda a vigilância permanente do Congresso (Jabor, 2013d). Recomendou a ligação com a imprensa que, segundo ele, é séria (Jabor, 2013f) e criticou com veemência a violência dos protestos, opondo-se exatamente àquilo que poderia transformar tudo e possibilitar a auto-instituição (Dupuis-Déri, 2014; Ludd, 2002; Gelderloos, 2011).

Enfim, a grande mídia disputou a direção do movimento e apresentou suas solicitações como se fossem a de todos. Foram os oligopólios de comunicação de massa os responsáveis pela organização de um grande setor nacionalista e institucional nas passeatas. Esses indivíduos portavam bandeiras nacionais, pintavam o rosto de verde e amarelo e bradavam contra a violência e os partidos políticos. Sua pauta foi bastante difusa e apresentou a corrupção como o principal problema do país. Só para dar uma ideia de como isto aconteceu, no programa RJ-TV da Rede Globo os jornalistas ensinaram como o manifestante tinha que se comportar e ainda dizia sobre a suposta pauta do movimento.

No terceiro momento, depois dos maiores protestos da história brasileira, os oligopólios de comunicação de massa, começaram a criticar os "vândalos", segundo eles, "formados por punks, marginais e radicais bolcheviques que queriam acabar com o movimento". Essa foi a estratégia da grande mídia: separar os manifestantes em legítimos, que portam verde e amarelo, e os ilegítimos que ela denominou de "vândalos" 14 , os quais atacam os prédios símbolos do governo, do grande capital e resistem aos ataques policiais.

Em novembro de 2013, Jabor (2013e) já defendia que "as manifestações se esvaíram por causa dos fascistas mascarados Black Blocs.” Essa afirmação precisa ser problematizada. Primeiro, chamar os Black Blocs de fascistas constitui-se em uma enorme demonstração de

federal e civis dos Estados e do Distrito Federal, respectivamente". A "grande" sugestão de Arnaldo Jabor resumia-se ao fato de o Ministério Público ficar de fora das investigações.

${ }^{14}$ Termo pouco preciso, mas amplamente utilizado pelos oligopólios de comunicação de massa no Brasil para depreciar os manifestantes que se defendiam dos ataques policiais e quebraram vidraças de bancos por consequência. Depois de exaustiva campanha de grande mídia, o termo vândalo virou quase um insulto público. 
ignorância. Segundo, esse foi o discurso hegemônico utilizado pela grande mídia para culpar os mais combativos pelo fim das manifestações. Terceiro, esta postura isentava os governos, comandantes dos polícias, pela forte repressão sobre os manifestantes, como responsáveis pela saída dos jovens das ruas, preocupados com a integridade física.

As teses de Jabor consubstanciam-se como a melhor representação do pensamento ultraliberal no Brasil, que inclusive, conseguem a proeza de criticar os governos petistas pela direita, como os partidos políticos PSDB, DEM, PPS e outros.

\section{Análises governistas}

Dentro desse veio analítico, estão vários intérpretes. Comecemos com o discurso oficial da presidente da República, proferido no dia 21 de junho de 2013. Neste, ela buscou condenar com toda força a violência de vários manifestantes contra as instituições e curiosamente estabeleceu uma orientação para o movimento:

[...] A mensagem direta das ruas é pacífica e democrática. Ela reivindica um combate sistemático à corrupção e ao desvio de recursos públicos. (...) Esta mensagem exige serviços públicos de mais qualidade. Ela quer escolas de qualidade; ela quer atendimento de saúde de qualidade; ela quer um transporte público melhor e a preço justo; ela quer mais segurança. Ela quer mais. E para dar mais, as instituições e os governos devem mudar (Rousseff, 2013).

Tratava-se apenas de um discurso para acalmar os ânimos populares, bastante exaltados, mas de concreto pouco foi realizado.

Parte dos intelectuais reproduziram acriticamente o estabelecido pela maior representante do Executivo no país, negando a tão cara e necessária independência de pensamento.

No interior desse campo esteve ainda a interpretação do porta-voz da presidência da República sob o governo Lula (2003-2007), André Singer (2014). Segundo ele, estavam nas ruas a classe média e o novo proletariado "favorecido pelo governo petista". Na azáfama desesperada de defender o governo, mas procurando se apresentar o mais isento possível, o autor traz números sobre a idade dos manifestantes, dentre outras insignificâncias, e conclui que "apenas $2 \%$ deles tinham mais de 60 anos" - nos protestos confrontacionais com a polícia. Desnecessário perdermos tempo explicando essa evidência estúpida. Ele ainda sugere uma hipótese bastante surreal: o governo petista, como de esquerda, vítima da direita nas ruas que queria menos impostos. 
Ricardo Musse (2013), apresentando-se como defensor da criação de uma frente da esquerda partidária, incluindo o governo, afirma que o descrédito dos partidos políticos e dos parlamentares e governantes em geral é uma criação da grande mídia, como se fosse uma conspiração para desqualificar o sistema representativo e abrir espaço para regimes autoritários. O autor ignora que a crise da representação política constitui-se enquanto fenômeno mundial. Musse (2013) chega ao desatino de classificar os governos de Rousseff e de Lula da Silva como nacional-desenvolvimentista e de "embrião do Estado de bem-estar social", respectivamente. Trata-se de uma interpretação típica governista sem nenhum amparo no teórico, muito menos no real.

É importante citar que os petistas, bem como os militantes do PCdoB também defenderam essa ideia. Argumentaram nas plenárias populares, quando não foram expulsos, que os fascistas dirigiam o movimento e preparavam um golpe militar contra o governo federal. Esses setores tentaram difundir a política do medo e, ao mesmo tempo, colocar o governo como grande vítima de uma conspiração de extrema direita no Brasil. Nada mais idílico.

A única diferença dessa tese para a de Arnaldo Jabor é que esta isentou o governo de qualquer responsabilidade, enquanto Jabor primou por criticá-lo sempre que pôde. Façamos agora a análise das interpretações da esquerda estatista.

\section{Características das análises da esquerda oficial-estatista}

A interpretação da esquerda oficial-estatista segue a tradição de Marx e Engels (principalmente sobre o que propuseram no Manifesto Comunista), depois ressignificada e materializada por Kautsky, Bernstein e inúmeros outros teóricos que propuseram a chegada ao socialismo por meio da participação institucional. Normalmente resumem tudo a um problema de gestão. Ela é propalada pela esquerda institucional. Estão em grande medida juntas as análises do PSTU, de setores majoritários do PSOL, PCB, e dos sindicatos e intelectuais alinhados às suas ideias. Por isso a principal demanda dos partidos e sindicatos da esquerda oficial foi "fora esse e aquele governante", apresentando-se como solução eleitoral para ocupar o lugar mal gerido pelo político da situação. Enfim, tudo foi resumido a uma contenda eleitoral. Uma boa parte dos aparelhos sindicais, dos centros acadêmicos estudantis e todos os partidos reformistas trabalharam para divulgar essa tese. Em função dessa lógica, eles precisaram estar em certa medida conectados com aquilo que foi amplamente divulgado 
pela grande mídia e com o impreciso conceito de opinião pública. Como não podiam se opor totalmente aos ditames midiáticos, suas posturas tenderam a ser centristas, fato que ajudou lateralmente a criminalizar os movimentos mais combativos da Revolta dos governados.

As análises reformistas, geralmente ligadas a partidos políticos eleitoreiros, tiveram uma interpretação ambígua do levante. Por um lado, vislumbraram a revolta como positiva, pois colocou em xeque os erros do governo (situação), ampliando suas possibilidades de se colocar como alternativa eleitoral (oposição). Por outro lado, como a insurreição popular nunca esteve sob seu controle, se mostrando arrediamente indomável, e, ainda, desaprovando todos os partidos políticos, esse viés interpretativo a criticou como sem direção, sem demandas claras, sem pauta, sem líderes, enfim, sem rumo.

Essa maneira de lê a conjuntura está diretamente embasada na perspectiva de que ele se julga como portador das únicas e boas conceituações e consequentemente das soluções ideais para todos. Esse campo se apresenta como herdeiro do marxismo-leninismo com todos seus projetos centralizadores, hierárquicos, estatistas, e embebido do juízo segundo o qual a vanguarda do proletariado deve dirigir todo e qualquer processo de insurgência. Não respeitála, nem se subordinar a ela constitui-se como uma aberração imperdoável. Na verdade o que está posto é que esse setor não consegue criticar profundamente a hierarquização social, por consequência, legitima a dicotomia entre direção e base, em resumo, entre governantes e governados. É claro que o comando do processo deve lhes pertencer, pois do contrário, segundo pensam, ele será inconsequente. Essa esquerda se coloca como portadora da verdade revolucionária (mesmo estando estritamente ligada ao dogma institucional-conservador) e, como verificamos ao longo do Levante não esteve aberta a fazer uma crítica de suas ações.

Num primeiro momento, esses partidos apoiaram o movimento. Inclusive, é importante dizer, muitos de seus militantes foram valiosos para que ele ocorresse. Sem embargo, no ápice dos protestos, trabalhadores e estudantes não pertencentes a partidos políticos compunham a extrema maioria e isso assustou a esquerda tradicional, sobretudo, porque o "povão", com razão, não entende os seus signos reformistas. Por consequência, esses para-governistas que tentaram dirigir o processo foram amplamente rechaçados nas passeatas em todo o Brasil, não conseguindo controlar de forma alguma a revolta popular, muito menos a sua pauta. Como resultado, mudaram o discurso. Passaram a interpretar as passeatas com ressalvas. Argumentavam que existiam três setores nas manifestações: 1) de direita (também chamado de: extrema-direita, nacionalista, e até fascista), sem uma reivindicação clara, sem 
comando, enfim, sem rumo, diziam, que gritavam "sem partido"; 2) dos radicais inconsequentes da esquerda revolucionária, também sem comando e sem rumo, diziam; 3) da esquerda "revolucionária" consequente, composta por eles mesmos, com comando e organização exemplares.

É importante entender que existe uma forte crítica ao papel exercido pelos militantes de partidos políticos nos sindicatos, nos centros acadêmicos e principalmente nos parlamentos, prefeituras, enfim, nos governos, não sem motivos, pela população. Normalmente, eles se apresentam para dirigir os demais, segundo as teses de seus mentores intelectuais, Marx e Engels, Lenin, Trotsky, Stalin, buscando aparelhar toda associação para seus anseios políticos-eleitorais, mas apresentados curiosamente como revolucionários. Nas próprias manifestações tentaram dirigi-las, colocando-se inclusive, nas primeiras passeatas, a frente de todos os demais, como que efetivamente liderassem seus "seguidores". As interpretações intelectuais que fazem parte desse campo são Osvaldo Coggiola (2013), Mauro Iasi (2013), Valério Arcary (2013), Henrique Canary (2013), Marcelo Badaró (2013).

\section{Considerações finais}

Percebemos ao longo da pesquisa, diferentes modelos de análises do mesmo fenômeno, sendo determinante o reconhecimento da posição político-ideológica do autor para identificarmos o seu foco, críticas e elogios sobre a revolta. Também observamos que é possível justificar diferentes e até antagônicas leituras do mesmo processo.

Vimos que as interpretações oficiais (governistas e ultraliberais) e da esquerda estatista, apesar de pequenas nuanças idiossincráticas, tiveram uma lamentável convergência, ajudando a destruir o movimento. Apresentamos algumas delas: 1) desqualificaram o Levante como sem pauta e sem direção; 2) defenderam a ideia de que o movimento estava sendo influenciado/dirigido por fascistas e/ou por grupos de direita; 3) negaram que a classe trabalhadora esteve massivamente presente no processo afirmando que se tratava de uma classe média; 4) advogaram pela preservação dos símbolos do Estado burguês e das instituições chamadas por antífrase de democráticas. As três primeiras teses buscaram desqualificar o movimento por uma pseudo composição social/política: classe média, direita e/ou fascistas; e por sua forma de organização: horizontal e descentralizada. A quarta tese convergente diz respeito a crença desses setores na institucionalidade burguesa e na 
democracia representativa por participarem como concorrentes eleitorais, legitimando, evidentemente, todo o processo com suas instituições e aberrações.

Os intelectuais, representados nas análises de Jabor tentaram usar o Levante para desgastar o governo petista e com total apoio dos oligopólios de comunicação de massa, que durante dois anos de intensa campanha desde 2013, sagraram-se vitoriosos, ao mobilizar muitas pessoas somente na cidade de São Paulo, pelo "Fora Dilma" em março de 2015. Já os governistas buscaram resguardar o governo federal de qualquer responsabilidade, mas sem apoio popular organizado e com a grande mídia como adversária, foi uma tentativa infrutífera. Tratou-se de claro entendimento da miopia da política (Bringel, 2013).

A perspectiva de análise revolucionária da Revolta dos governados de 2013 no Brasil foi a única que se caracterizou pelas ausências das amarras institucionais que normalmente reduzem a leitura a uma disputa eleitoral. Com efeito, pôde valorizar o Levante como ele foi (Bringel, 2013; Cava e Cocco, 2014; Ferreira, 2015).

Por fim, do nosso ponto de vista, a revolta dos governados, principalmente a partir da nossa experiência na cidade do Rio de Janeiro, deverá ficar na história como aquele que teve como alvos principais os símbolos do Estado, do capitalismo, da democracia representativa e dos oligopólios de comunicação de massa. O Brasil entrou no calendário de lutas contra o capital e o Estado por meio da ação direta e com a tentativa de autoinstituição. Além do mais, percebemos que os protestos no Brasil seguiram uma tendência dos novos tempos iniciada nos EUA (1999) com as lutas da Ação Global dos Povos. Se em Seattle a descentralização apresentou-se como a ideologia do movimento sendo positivamente interpretada (Graeber, 2011; Dupuis-Déri, 2014, Ludd, 2002), podemos dizer que no Brasil não foi diferente. Procuramos com esse texto reparar uma dívida dos intelectuais com os diversos coletivos autônomos, evitando a prática tão comum na academia do epistemicídio, praticada pelos descendentes de Kautsky e de Nozick de forma convergente e simultânea. 


\section{Referências}

ARCARY, Valério.2013. Não deixem abaixar as bandeiras vermelhas. Disponível em: http://www.correiocidadania.com.br/index.php?option=com_content\&view=article\&id=8500: submanchete210613\&catid=63:brasil-nas-ruas\&Itemid=200. Acesso em 27 jul. 2014.

BADARÓ, Marcelo Badaró. 2013. A multidão nas ruas: construir a saída de esquerda para a crise política, antes que a reação imprima sua direção. Disponível em:

http://www.correiocidadania.com.br/index.php?option=com_content\&view=article\&id=8528: submanchete250613\&catid=63:brasil-nas-ruas\&Itemid=200. Acesso em 25 jul. 2014.

BAKUNIN, Michael. A Comuna de Paris e a noção de Estado. In: O princípio do Estado e outros ensaios. São Paulo: Hedra, 2008.

BARBUY, Victor Emanuel Vilela. 2013a. Resposta ao portal último segundo. Disponível em: http://www.integralismo.org.br/?cont=781\&ox=235 Acesso em 27 jul. 2014.

2013b. Um fantasma ronda o Brasil. Disponível em:

http://www.integralismo.org.br/?cont=781\&ox=237 Acesso em 27 jul 2014.

BRINGEL, B. 2013. Miopias, sentidos e tendências do levante brasileiro de 2013. Disponível em: http://www.insightinteligencia.com.br/62/PDFs/pdf3.pdf. Acesso em 27 jul. 2014.

CANARY, Henrique. 2013a. Anarquismo e socialismo: o individual e o coletivo nas mobilizações de massas. Disponível em: http://www.pstu.org.br/node/19465 Acesso em 27 jul. 2014.

2013b. Marxismo e anarquismo. Disponível em: http://www.pstu.org.br/node/20138 Acesso em 27 jul. 2014.

CARDOSO, Adalberto. 2013. As jornadas de junho e a mercantilização da vida coletiva. Disponível em: http://www.insightinteligencia.com.br/pdfs/62.pdf Acesso em 27 jul. 2014.

CASTORIADIS, Cornelius. A instituição imaginária da sociedade. Rio de Janeiro: Paz e Terra, 2010.

Figuras do pensável. Rio de Janeiro: Civilização Brasileira, 2004. 
CAVA e COCCO. Amanhã vai ser maior - o levante da multidão no ano que não terminou. São Paulo: Annablume, 2014.

CHAUI, Marilena. 2013. Uma nova política é possível? Disponível em: http://www.teoriaedebate.org.br/materias/nacional/manifestacoes-de-junho-de-2013-nacidade-de-sao-paulo Acesso em 20 jul 2014.

CHOMSKY, Noam. Mídia: propaganda política e manipulação. São Paulo: Martins Fontes, 2013.

COGGIOLA, Osvaldo. 2013. O Brasil foi para a rua: e agora? Disponível em: http://blogdaboitempo.com.br/2013/08/23/o-brasil-foi-para-a-rua-e-agora/ Acesso em 10 ago. 2014.

DUPUIS-DERI, Francis. Black Blocs. São Paulo: Veneta, 2014.

FERRAZ, Eduardo. 2013. Resposta a uma crise. Disponível em:

http://www.integralismo.org.br/?cont=781\&ox=231 Acesso em 11 ago. 2014.

FONTANA, Josep. A história dos homens. Bauru: EDUSC, 2004.

FERREIRA, Andrey Cordeiro. A festa e a revolta: confrontando as leituras de junho de 2013 com uma antropologia política das rebeliões populares. Disponível em:

https://nepcpda.wordpress.com/2015/06/18/a-festa-e-a-revolta-confrontando-as-leituras-dejunho-de-2013-com-uma-antropologia-politica-das-rebelioes-populares/ Acesso em 20 jun 2015.

FREYRE, Gilberto. Casa Grande \& Senzala. $34^{\text {a }}$ ed. Rio de Janeiro: Record, 1998.

GRAEBER, David. The new anarquists. New Left Review, Jan-feb 2002, v.13, p. 61-73. Fragmentos de uma antropologia anarquista. Porto Alegre: Deriva, 2011.

GELDERLOOS, Peter. How a nonviolence protects the state. Cambridge: South End, 2007. 
HARDT, Michael; NEGRI, Antonio. Império. Rio de Janeiro: Record, 2001.

HERNANDEZ, H. Maio de 1968: o início de uma luta prolongada? In: Maio de 68: os anarquistas e a revolta da juventude. São Paulo: Imaginário, 2008, p. 25-64.

HOLANDA, Sergio Buarque de. Raizes do Brasil. 26ª ed. São Paulo: Companhia das Letras, 2001.

IASI, Mauro. 2013. Pode ser a gota d'agua: enfrentar a direita avançando a luta socialista. Disponível em: http://blogdaboitempo.com.br/2013/06/26/pode-ser-a-gota-dagua-enfrentar-adireita-avancando-a-luta-socialista/ Acesso em 3 ago. 2014.

. A rebelião, a cidade e a consciência. In: MARICATO, Ermínia [et al.]. Cidades rebeldes: Passe livre e as manifestações que tomaram as ruas do Brasil. São Paulo: Boitempo, 2013b.

JABOR, Arnaldo. 2013a. Disponível em: http://globotv.globo.com/rede-globo/jornal-daglobo/v/arnaldo-jabor-fala-sobre-onda-de-protestos-contra-aumento-nas-tarifas-deonibus/2631566/ Acesso em 27 jul. 2014.

. 2013b. Disponível em: http://oglobo.globo.com/cultura/passe-livre-vale-mais$\underline{8717407}$ Acesso em 27 jul. 2014.

2013c. Disponível em: http://cbn.globoradio.globo.com/comentaristas/arnaldojabor/2013/06/18/DE-REPENTE-O-BRASIL-VIROU-UM-MAR.htm Acesso em 27 jul. 2014.

. 2013d. Disponível em: http://cbn.globoradio.globo.com/comentaristas/arnaldojabor/2013/06/19/SE-DEREM-MOLEZA-TUDO-VIRA-PO.htm Acesso em 27 jul. 2014.

2013f. Disponível em: http://cbn.globoradio.globo.com/comentaristas/arnaldojabor/2013/06/21/O-QUE-PODE-ESVAZIAR-O-PASSE-LIVRE.htm Acesso em 27 jul. 2014.

. 2013e. Disponível em: http://cbn.globoradio.globo.com/comentaristas/arnaldojabor/2013/11/22/BLACK-BLOCS-SAO-ALIADOS-DO-QUE-HA-DE-PIOR-NOBRASIL.htm Acesso em 28 jul. 2014. 
KROPOTKIN, Piotr. Os princípios anarquistas e outros ensaios. São Paulo: Hedra, 2007.

Palavras de um revoltado. São Paulo: Imaginário, 2005.

LIPSET, S. M. Political Man: The Social Bases of Politics. Garden City, Anchor Books, 1963

LOWY, Michel. O movimento passe livre. Disponível em:

http://blogdaboitempo.com.br/2014/01/23/o-movimento-passe-livre/ Acesso em 20 jul. 2014.

LUDD, Nedd. 2002. Urgência das ruas: Black Block, Reclaim The Streets e os Dias de Ação Global. Disponível em: https://we.riseup.net/assets/70965/Urgencia-Das-Ruas-ColetivoBaderna.pdf Acesso em 5 ago. 2014.

MAKHNO, Nestor. Nestor Makhno e a revolução social na Ucrânia. São Paulo: Imaginário, 2001.

MARICATO, Ermínia [et al.]. Cidades rebeldes: Passe livre e as manifestações que tomaram as ruas do Brasil. São Paulo: Boitempo, 2013.

MARICATO, Ermínia. Quando novíssimos atores entram em cena conquistas inesperadas acontecem. Disponível em: http://blogdaboitempo.com.br/2013/09/05/quando-novissimosatores-entram-em-cena-conquistas-inesperadas-acontecem Acesso em 20 jul. 2014.

Movimento Passe Livre - São Paulo. Não começou em Salvador, não vai terminar em São Paulo. In: MARICATO, Ermínia [et al.]. Cidades rebeldes: Passe livre e as manifestações que tomaram as ruas do Brasil. São Paulo: Boitempo, 2013.

MUSSE, Ricardo. 2013. A Potência das Manifestações de Rua. Disponível em: http://blogdaboitempo.com.br/2013/07/10/a-potencia-das-manifestacoes-de-rua/ Acesso em 20 jul. 2014.

NEGRI, Antonio. Poder Constituinte: ensaio sobre as alternativas da modernidade. Rio de Janeiro: DP\&A, 2002. 
OLIVEIRA, Francisco de. Entrevista a Ricardo Galhardo do Site IG - dia 7 de julho de 2013. Disponível em: http://ultimosegundo.ig.com.br/politica/2013-07-07/as-manifestacoesnao-foram-nada-demais-diz-o-sociologo-francisco-de-oliveira.htmlAcesso em 20 jul. 2014.

ROUSSEFF, Dilma. Discurso oficial proferido no dia 21 de junho de 2013. Disponível em: http://www2.planalto.gov.br/acompanhe-o-planalto/discursos/discursos-dapresidenta/pronunciamento-da-presidenta-da-republica-dilma-rousseff-em-cadeia-nacionalde-radio-e-tv Acesso em 11 ago. 2014.

SANTOS, Wanderley Guilherme dos. 2014. A Nova Era da Violência. Disponível em: http://www.cartamaior.com.br/?/Editoria/Politica/A-nova-era-da-violencia/4/30257 Acesso em 3 ago. 2014.

SINGER, André. Rebellion in Brazil. New Left Review, jan-feb 2014, v.85, p. 19-37.

VAINER, Carlos. Quando a Cidade vai às Ruas. In: MARICATO, Ermínia [et al.]. Cidades rebeldes: Passe livre e as manifestações que tomaram as ruas do Brasil. São Paulo: Boitempo, 2013a.

. 2013b. Mega-Eventos, Mega-Negócios, Mega-Protestos. Disponível em: http://blogdaboitempo.com.br/2013/09/02/mega-eventos-mega-negocios-mega-protestos/ Acesso em 27 jul. 2014. 